AAAJ

30,5

1142

\title{
The relationship between transformational client leadership and auditor objectivity
}

\author{
Jan Svanberg and Peter Öhman \\ Department of Business, Economics and Law, \\ Mid Sweden University, Sundsvall, Sweden and \\ Centre for Research on Economic Relations, Mid Sweden University, \\ Sundsvall, Sweden, and \\ Presha E. Neidermeyer \\ Department of Accounting, West Virginia University, Morgantown, \\ West Virginia, USA
}

\begin{abstract}
Purpose - The purpose of this paper is to investigate whether transformational leadership affects auditor objectivity.

Design/methodology/approach - The investigation is based on a field survey of 198 practicing auditors employed by audit firms operating in Sweden.

Findings - This study finds that transformational client leadership negatively affects auditor objectivity and that the effect is only partially mediated by client identification. Given these results, suggesting that auditors are susceptible to influence by their clients' perceived exercise of transformational leadership, leadership theory appears relevant to the discussion of auditor objectivity in the accounting literature.

Originality/value - Previous accounting research has applied the social identity theory framework and found that client identification impairs auditor objectivity. However, the effect of transformational client leadership on auditor objectivity, which reflects an intense auditor-client relationship, has been neglected before this study.
\end{abstract}

Keywords Auditor objectivity, Client identification, Transformational client leadership

Paper type Research paper

\section{Introduction}

Accounting research has provided substantial evidence of the impact of financial incentives on auditor objectivity (e.g. Salterio, 1996; Mayhew et al., 2001; Kadous et al., 2003; Umar and Anandarajan, 2004; Hollingsworth and Li, 2012). This body of research has been extended to consider non-financial incentives, as advocated by Bamber and Iyer (2007). Their findings suggest that auditors tend to identify with their client firms and that client identification is negatively related to auditor objectivity. This effect has been confirmed, and the results have been extended by recent research (Stefaniak et al., 2012; Bauer, 2015; Svanberg and Öhman, 2015).

The dramaturgy is not so much about the shift of focus from financial to non-financial dependence-related factors as about the implication that auditors' social identities appear highly relevant to the audit context. The importance of social identities can be understood with the aid of leadership research, which describes leadership as a process that derives its effectiveness to a substantial extent from follower identity. In essence, this means that it is easier to influence individuals if they identify with a collective to which the leadership is relevant. Since accounting research has found that auditors tend to identify with their client firms, they may be affected by client leadership.

This study focuses on transformational leadership, which has been one of the most empirically examined types of leadership over the past 30 years (van Knippenberg and Sitkin, 2013), and on whether the extent to which auditors perceive the chief financial officers of their largest clients (the client's CFO) as transformational is associated with 
the impairment of auditor objectivity. The leadership literature argues that the more that followers identify with a group, the more susceptible these followers are to transformational leadership (Howell and Shamir, 2005). Extensive research also demonstrates that transformational leadership increases the tendency of followers to identify with the leader's group or organization (Conger et al., 2000; Shamir et al., 2000; Duck and Fielding, 2003). Several studies have reported that collective identification partially mediates the impact of transformational leadership on follower behavior (e.g. Conger et al., 2000; De Cremer and van Knippenberg, 2002; Kark et al., 2003). Even though auditors and clients are not members of the same organization, the fact that auditors identify with their clients provides reason to suspect that auditors are susceptible to transformational client leadership.

We apply a cross-sectional design in order to study the association between auditor perception of transformational client leadership and auditor judgment. We ask each auditor to imagine a scenario concerning his or her largest client in which the auditor thinks that an accounting issue concerning unrecorded liabilities is material, however, the client disagrees. We measure the auditor's lack of objectivity as his or her degree of acceptance of the client's point of view; we ask the auditor to imagine the leader in client management responsible for the client firm's financial reports (i.e. the $\mathrm{CFO}$ ) when completing an instrument measuring transformational client leadership, and we measure the auditor's client identification using a measurement instrument validated in previous research. We anticipate that higher levels of perceived transformational client leadership will be associated with a more lenient audit judgment than will lower levels. We also expect this association to be mediated by the extent to which auditors identify with their clients' firms. Our results indicate that higher levels of perceived transformational client leadership are associated with more lenient audit judgments than are lower levels, and that this association is partially mediated by the strength of auditors' client identification.

The present study is important to regulators, auditors and accounting research because it examines a previously uninvestigated threat to auditor objectivity. More precisely, it extends the accounting literature that has previously examined financial incentives (e.g. Kadous et al., 2003; Hollingsworth and Li, 2012) and social incentives (e.g. Bamber and Iyer, 2007; Stefaniak et al., 2012) as mechanisms impairing auditor objectivity.

Moreover, the mediating relationship suggests that transformational client leaders may inspire higher levels of identification with client firms than do less transformational leaders, a conclusion supported by the leadership literature (e.g. De Cremer and van Knippenberg, 2002; Kark et al., 2003, 2012). This result calls into question the prior narrow focus in the accounting literature on the role of client identification as a main force that constrains audit judgment. The leadership literature describes collective identification as one of several intermediary effects in the process of influence, and applying a leadership perspective on the auditor-client relationship is one way to broaden research into auditor objectivity.

Finally, while most previous studies of auditors' potential client-dependency as a result of non-financial incentives are set in US Big 4 firms among the largest of clients, transformative leadership can affect auditor objectivity regardless of client size. Our results, from a sample of smaller client firms than those examined in Bamber and Iyer (2007) and Stefaniak et al. (2012), confirm this proposition as to the impact of transformative leadership on auditor objectivity. Any firm may have transformational leaders and smaller clients are more likely than larger clients to facilitate direct communication between top client management and auditors.

The remainder of the paper is organized as follows: the next section presents the theoretical framework, and then the research method is outlined. The findings are then presented, after which a discussion concludes the paper. 
AAAJ

30,5

1144

\section{Theoretical framework}

\subsection{Transformational client leadership and auditor objectivity}

Transformational leadership is defined as either a set of effective leadership behaviors (Bass, 1985) or as follower perceptions of leader behaviors (Lowe et al., 1996; Kark et al., 2003). This study adopts the latter definition, conceptualized in the leadership literature as consisting of four dimensions of leader behavior: inspirational motivation, idealized influence, intellectual stimulation and individualized consideration (Bass and Avolio, 1995). Inspirational motivation is the leader articulating a compelling vision of the future and behaving as though that vision is extraordinary. Idealized influence means engaging in transformational actions that earn respect and cultivate pride, discussing important values and beliefs, communicating a sense of purpose, and nurturing a focus on collective interests (interests that contribute to achieving the vision). Intellectual stimulation involves challenging followers to question their assumptions and think differently. Individualized consideration involves personal interactions with followers that provide relevant mentoring, coaching and understanding.

The transformational theory of leadership, which has gained widespread acceptance, has been further developed, using social psychology, into the identity theory of leadership (van Knippenberg et al., 2004). Transformational leadership boosts follower identification with the leader (Hobman et al., 2011) and, more importantly, increases identification with the organization by leveraging the attractiveness of the leader's vision (De Cremer and van Knippenberg, 2002; Kark et al., 2003; Epitropaki and Martin, 2005). Having a strong organizational identification means feeling as if one belongs and is psychologically intertwined with the organization, sharing its fate, successes and failures (Mael and Ashforth, 1992). The effectiveness of transformational leadership is at least partly due to its ability to shift followers' perspectives from self-interest to collective interest by increasing collective identification. This close relationship suggests that the effects of transformational leadership are the same as or similar to the effects of organizational identification, i.e. increased citizenship behavior, job satisfaction, and reduced turnover intentions, and the leadership literature indeed finds such effects (Riketta, 2005; Boroş et al., 2011). There is also empirical evidence of the relationship between transformational leadership, collective identity and follower behavior (DeRue et al., 2011). When leaders are exemplary role models, articulate a compelling vision, emotionally appeal to followers and communicate high performance expectations, followers are encouraged to work hard to achieve the firm's goals and objectives (Shin and Zhou, 2003).

As findings in the accounting literature suggest that auditors identify with their largest clients (Bamber and Iyer, 2007), we anticipate that, if the client is able to exercise leadership that connects with this part of an auditor's identity, then auditors may be susceptible to client influence through leadership behaviors in client firms of any size. We would expect transformational client leadership to influence auditor objectivity even in the absence of auditor-client identification because it has a strong record of affecting behavior in many contexts (Lowe et al., 1996; Dvir et al., 2002; Bass et al., 2003; Wang et al., 2005; Schaubroeck et al., 2007; Walumbwa et al., 2008).

Two main objections can be raised against our proposition that transformational leadership may impair auditor objectivity. First, auditors are not members of the client organization and are not subject to direct client management. However, this objection does not quite hold. Organizational boundaries and identity differences may make leadership less effective, but this is not an insurmountable obstacle to leadership because leaders can influence people across formal dividing lines in situations such as joint ventures (Hambrick et al., 2001). Leadership is defined in the leadership literature as a relationship between leaders and followers regardless of whether there is any formal relationship (Yukl, 1998). Auditors often need to negotiate with client management to resolve issues about which 
auditors and clients have different views (Beattie et al., 2001; Gibbins et al., 2005, 2010; McCracken et al., 2008; Hellman, 2011). This negotiation constitutes the type of repeated interaction that may lead to a relationship between auditors and clients that may present opportunities to exercise transformational leadership.

Second, auditors are governed by strong professionalism that could make it difficult for other competing forces to influence audit judgment. However, this objection does not hold either. In line with the social psychological literature, LeBoeuf et al. (2010) and Bauer (2015) argue that not only does the strength of identity influence behavior, but also that the situationally triggered salience of an identity is an important determinant of behavior. Given the results of LeBoeuf et al. (2010) and Bauer (2015), an auditor with strong client identification is more likely to agree with the client only if his or her professional identity is not made salient by the situation. Although none of these studies refers to leadership, their results suggest that being internally client-oriented can affect an auditor's judgment if his or her professional identity is not made salient by situational triggers.

There are several reasons to expect a drop in auditor objectivity as a result of transformational client leadership. Followers who are under the influence of a transformational leader are willing to transcend self-interest for the sake of the collective (i.e. team or organization), to engage in self-sacrifice in the interest of the mission, to identify with the vision articulated by the leader, to demonstrate strong emotional attachment to the leader, to internalize the leader's values and goals, and to demonstrate strong personal or moral commitment as opposed to calculative commitment to those values and goals (e.g. Bass, 1985; House et al., 1991). These are perceptions that lead to a high level of admiration, respect and even reverence for the leader (Conger et al., 2000; Walumbwa et al., 2004), in turn strengthening trust in the information the leader provides (Conger et al., 2000). Transformational leaders build trust by advocating their position in a disinterested manner, demonstrating concern for followers' needs rather than self-interest, and displaying total dedication to a common cause. The transformational leader is typically perceived as benevolent (Mayer et al., 1995), a fact that increases follower susceptibility to leader influence (Giessner and van Knippenberg, 2008). These effects could threaten auditor objectivity if they materialize in the auditor-client relationship. If this form of influence is possible, clients may be interested in using it. In fact, Hellman (2011) finds that 97 percent of clients try to control, and succeed in controlling, the audit starting from the planning stage. Similarly, Sweeney and Pierce (2011) argue that clients can easily influence their auditors.

The effects of transformational leadership on pro-organizational behavior, and of the transcending of individual self-interest (Den Hartog et al., 1997) in terms of benefiting a group or organization, seem undisputed. One point that needs clarification in this context is the claim made by some leadership research that transformational leadership is essentially or inherently ethical (Avolio, 1999; Peus et al., 2010). The claim is understandable in light of earlier research that linked the notion of transcending self-interest to such higher values as professional obligations and societal benefits. Transcending self-interest, however, also means replacing self-interest with collective interest, which is often the interest of a company. Perceiving motivation for a purpose as tied to organizational goals is a way for a business to build commitment without having to increase the paycheck. In the auditing context, this means that auditors can be persuaded to feel involved in and motivated to support the client firm's or client management's objectives (cf. Jenkins and Lowe, 1999). The social identity theory of transformational leadership (Shamir et al., 2000) entails the possibility that one set of individual or professional motivating identities may compete to some extent with the auditor's client identification, and we anticipate that a transformational client leader can increase the strength or salience (or both) of the auditor's client identification and thus increase the likelihood of the auditor's judgment being constrained. 
AAAJ

30,5

1146

Although the individual level of identity, at which behavior is governed by self-interest, is also relevant to the auditing context, our focus is on identification with the client firm and with the profession. The ethicality of transformational leadership in this context appears not inherent to this form of leadership. The auditor who is not supposed to identify with the client runs the risk of unethical behavior as an effect of identification with the client firm. Furthermore, neither of the frequently used measurement instruments for transformational leadership - the multifactor leadership questionnaire (Bass and Avolio, 1995) or the transformational leadership inventory (Podsakoff et al., 1990) incorporates ethical dimensions. This is of interest because Effelsberg et al. (2014) report that transformational leadership entails the risk of encouraging followers to contribute to their company's success in ways that are generally considered unethical, this effect being mediated by the followers' identification with the company. In the same vein, Umphress et al. (2010) report that organizational identification leads to an increasing likelihood of unethical but pro-organizational behavior. It therefore appears that individuals may be encouraged to deviate from societal norms in favor of narrower company interests. Analogously, because auditors tend to identify with their client firms (Bamber and Iyer, 2007; Stefaniak et al., 2012; Svanberg and Öhman, 2015), they may acquiesce to client-preferred accounting positions despite the ethical aspects and potential outcomes of their decisions (cf. Sweeney and Pierce, 2006).

Finally, theory predicts and empirical studies have demonstrated that the four dimensions of transformational leadership are highly correlated and can be understood as derived from the higher-order construct of transformational leadership (Bass, 1985; Kark et al., 2003; Shin and Zhou, 2003; Judge et al., 2004; Walumbwa et al., 2004, 2008; Piccolo and Colquitt, 2006; Liao and Chuang, 2007; Walumbwa and Hartnell, 2011). Because there are no theoretical reasons for expecting differential relationships between the four dimensions of transformational leadership and auditor objectivity, we treat transformational leadership as a single variable. Taken together, the cited leadership studies indicate that a transformational client leader may have a negative effect on the objectivity of auditor judgment. We state this hypothesis as follows:

H1. There is a negative relationship between the extent to which their clients' leaders exercise transformational leadership and auditors' objectivity.

\subsection{Auditor-client identification}

Follower identity has a decisive influence on the effects of leadership behavior (Hogg, 2001; Hogg and van Knippenberg, 2003; van Knippenberg and Hogg, 2003). There is substantial evidence outside the accounting field that followers' social identities mediate the impact of transformational leadership on follower behavior (e.g. Kark et al., 2003; Epitropaki and Martin, 2005; Effelsberg et al., 2014). This evidence, combined with the findings of Bamber and Iyer (2007) that auditors identify with their clients, suggests the importance of examining whether auditor-client identification mediates the effect of transformational client leadership on auditor objectivity.

The social identity theory of leadership suggests that self-construal in collective terms is likely to render collectivistic values salient, providing motivation to contribute to the collective (Shamir, 1990). A first influence on the group member is directly connected to group membership and means that one must submit to a degree of social control that is partly normative and partly cognitive. A second influence is that a group member sees the self through the lens of social identity, causing the member to take the group's interests to heart, essentially transforming group interest into self-interest (De Cremer and Van Vugt, 1999; van Knippenberg, 2000). This definition of the self in collective terms leads to increased intrinsic motivation to act in the interest of the group. Such influences make it 
difficult for any group member to maintain objectivity vs the group, and the auditor should be no exception. Although the auditor is not an actual member of the client organization, previous evidence of auditor identification with client firms and the evidenced effect on auditor objectivity (Bamber and Iyer, 2007) indicate that there is a substantial risk that group-related influences might impair auditor objectivity.

Regarding the relationship between transformational leadership and social identification, De Cremer and van Knippenberg (2002) found that identification with the collective mediated the interactive effect of leader self-sacrifice and leader procedural fairness on follower cooperation. Kark et al. (2003) found that social identification mediates the impact of transformational leadership on empowerment. In addition, social identification with a collective can be increased by transformational leadership (Conger et al., 2000; Shamir et al., 2000; Duck and Fielding, 2003). These findings support the idea that transformational leadership derives part of its effectiveness from its effect on follower identification with the collective.

Previous leadership research and the self-concept-based theory of leadership suggest that social identification mediates the effect of transformational leadership on follower behavior. In the audit context, we expect that clients who exercise transformational leadership will influence their auditors in such a way that auditor objectivity is impaired. We also expect this effect to be mediated by the auditor's client identification, and accordingly formulate the following hypothesis:

H2. The impact of transformational client leadership on auditor objectivity is mediated by auditor identification with the client firm.

\section{Method}

\subsection{The context}

This study was conducted in Sweden. In recent decades, the number of certified public accountants (CPAs) in Sweden has been approximately 4,000, although the number has decreased slightly in recent years. Revisorsnämnden (the Supervisory Board of Public Accountants) issues certifications and supervises CPAs and audit firms, and litigation rates against Swedish auditors are relatively low (Carrington et al., 2013).

The total number of listed companies in Sweden is approximately 300. This means that such companies constitute a very small proportion of all companies, with small- and medium-sized companies constituting the vast majority of companies. Swedish limited companies not listed on the stock exchange are not obliged to establish audit committees. In these companies, management may be significantly involved in the selection process that precedes the appointment of auditors by the general meeting of shareholders. Moreover, interaction between auditors and client management is obvious in many Swedish companies (Hellman, 2011; Carrington et al., 2013).

Despite some distinguishing features, both Sweden and most English-speaking countries have adopted IFAC's International Standards on Auditing. The presence of the Big 4 firms in Sweden is similar to their presence in most other countries, and these firms dominate the Swedish audit market. In addition, expectations that ethical problems and auditor objectivity constraints could affect relationships between auditors and client firms are applicable to Sweden as well (Öhman and Wallerstedt, 2012; Svanberg and Öhman, 2016).

\subsection{Research design}

We conducted a cross-sectional survey asking auditors to recall their largest client and to think of the leader of this client (referred to as the CFO in the questionnaire). The focus was on the client management leader who is responsible for the client firm's financial and control functions, and who typically interacts a great deal with auditors (cf. Gibbins et al., 2005;

\section{leadership and auditor objectivity}

1147 
AAAJ

30,5

1148

McCracken et al., 2008; Hellman, 2011), because we wanted auditors to assess whether they perceived a given visible leader as transformational. The auditors assessed the leader's degree of transformational leadership by completing a well-documented transformationalleadership instrument. They were also asked to make a decision about a case describing a material accounting issue involving their largest client. We measured the extent to which the auditor's decision about the case expressed concession to the client leader's desired accounting treatment, focusing on the association between auditor perception of transformational client leadership and auditor concession to client requirements.

Leadership could have been defined and measured using alternative approaches, but most leadership research into the effects of transformational leadership has adopted the measurement of perceived transformational leadership used here or similar versions of this instrument (cf. van Knippenberg and Sitkin, 2013).

\subsection{Sample and data collection}

A random sample of 1,000 Swedish auditors was selected using a register of the Swedish Supervisory Board of Public Accountants. A questionnaire for collecting data, modeled partly on the Multifactor Leadership Questionnaire (MLQ 5X) and partly on the questionnaire of Bamber and Iyer (2007), was pilot-tested by two authorized auditors to improve the clarity of the items before being e-mailed using survey software. The questionnaire, distributed in October 2014, took auditors approximately 10-15 minutes to complete according to the pilot testing. We informed the respondents that participation in the study was voluntary and that we would use the obtained information for scientific purposes only. The respondents were also informed that the collection of responses through the e-mail system ensured anonymity because the survey software did not enable tracking of respondent identity. Respondent anonymity was a key issue because of the risk of social desirability bias that plagues behavioral ethics research, and because of the risk of low response rates, which is a general problem in survey research. We obtained 198 useful responses, representing a 19.8 percent response rate. This response rate was achieved after reminding the respondents three times over a period of three weeks.

Non-response bias was examined using a method described by Larson and Catton (1959). We treated the difference between late and early respondents as a measure of non-response bias, i.e. non-respondents' answers were taken to be represented by late respondents' answers. Analyzing the results using the Kruskal-Wallis $\mathrm{H}$ test, we found no significant differences between the two groups of respondents. This examination provides some assurance against non-response bias in the sample.

\subsection{Measures}

For the leader of each auditor's largest client (i.e. the CFO), transformational leadership was measured using a questionnaire rephrasing the transformational items of MLQ 5X (Bass and Avolio, 1995). The 20 items were adapted to fit the audit context and the questions were translated into Swedish. The result was a measurement instrument with four subscales approximating the MLQ 5X. Previous research has demonstrated that the four dimensions of MLQ 5X are highly correlated (at 0.93 after correction for unreliability; see Judge et al., 2004). Thus, consistent with previous studies (e.g. Bono and Judge, 2003; Kark et al., 2003; Shin and Zhou, 2003; Walumbwa et al., 2004, 2008; Liao and Chuang, 2007), we formed a composite transformational leadership index (Cronbach's $\alpha=0.962$ ) using principal component analysis. Respondents were asked to indicate the frequency with which the client leader engaged in each of the behaviors on a ten-point Likert-type scale ranging from strongly disagree (1) to strongly agree (10). Sample items are provided in the Appendix.

We adapted the measure of client identification from the organizational identification scale (Wan-Huggins et al., 1998), using a rephrased version developed by Bamber and Iyer (2007) to 
measure client identification in the audit context. The items, described in the Appendix, contained ten-point Likert-type scales ranging from strongly disagree (1) to strongly agree (10). Using principal component analysis, we ensured that the client identification items loaded on one-component. The internal reliability (Cronbach's $\alpha$ ) of the client identification scale was found to be 0.85 .

The questionnaire also contained a short case adapted from Bamber and Iyer (2007) describing auditor behavior in an audit conflict situation involving the largest client. The auditors' responses to this case provided a measure of auditor objectivity. The case describes a situation in which the auditor's conclusion is that unrecorded liabilities are material but the client's management strongly disagrees. Respondents were asked about the likelihood that they would accept the client-preferred treatment and not require that the liabilities be recorded in the financial statements, indicating their response on a probability scale extending from very high likelihood (1) to very low likelihood (10).

Finally, the auditors' financial dependence on the client was measured using the proxy client size in terms of annual turnover (SEK millions) for each auditor's largest client firm. Auditor age, experience in years and tenure in years were measured using one item each. We measured the type of audit firm by asking whether or not the auditors were employed in a Big 4 firm.

\section{Analysis and results}

\subsection{Descriptive statistics}

Table I shows that most respondents are men and that the distribution between Big 4 and non-Big 4 auditors is almost even. On average, the respondents are almost 48 years old and have been auditors for 21 years. The average length of time that an auditor has audited his or her largest client is eight years.

The auditors' client acquiescence score in Table I refers to the likelihood that auditors would accept a client-preferred treatment and not require that material liabilities be recorded in the financial statements. As this item is coded and reported, it corresponds to auditor objectivity. A high score in Table I indicates a high probability of negative comments regarding the client-preferred treatment, which means a low degree of leniency

\begin{tabular}{|c|c|c|c|c|c|c|}
\hline Variables & Frequency & Mean & $\mathrm{SD}$ & Median & Min & Max \\
\hline Male & 146 & & & & & \\
\hline Female & 52 & & & & & \\
\hline Big 4 & 102 & & & & & \\
\hline Non-Big 4 & 97 & & & & & \\
\hline Age (years) & & 47.60 & 10.84 & 48 & 29 & 75 \\
\hline Auditor experience (years) & & 21.02 & 8.92 & 24 & 5 & 41 \\
\hline Auditor tenure (years) & & 8.11 & 5.10 & 7 & 2 & 25 \\
\hline Auditor's client acquiescence (1-10) & & 8.02 & 2.13 & 9 & 1 & 10 \\
\hline Transformational leadership (1-10) & & 5.73 & 1.81 & 5.95 & 1.45 & 8.80 \\
\hline Client identification (1-10) & & 3.82 & 1.99 & 3.40 & 1 & 9.80 \\
\hline Client size (turnover, SEK millions) & & $3,100.42$ & $13,956.44$ & 200 & 30 & 100,000 \\
\hline
\end{tabular}

Notes: Variables: "Age" is the auditor's age in years. "Auditor experience" is the number of years the auditor has worked as an auditor. "Auditor tenure" is the length of time that the auditor has audited the largest client. "Auditor's client acquiescence" measures the extent to which an auditor is lenient toward the client-preferred treatment (here we report the raw data value, which for this variable means that 1 indicates totally lenient and 10 not lenient at all); in subsequent tables we have reverse scored this variable. "Transformational leadership" is a one-component representation of transformational client leadership. "Client identification" is a variable capturing the extent to which an auditor identifies with a client. "Client size" is the turnover of the auditor's largest client (SEK millions: USD 1 = SEK 8.52 - June 27, 2016)
Client leadership and auditor objectivity

1149 
AAAJ

30,5

1150

toward client management. The average score of 8.02 indicates that the sampled auditors would frequently choose to communicate the problem. The average transformational leadership score of 5.73 is just above the scale midpoint, indicating that the average auditor does perceive client leaders as transformational. The SD of 1.81 indicates variation between respondents. While some respondents perceive their client leaders as far from transformational, others characterize the leader of their largest client as clearly transformational. Table I also shows that the average client identification value is 3.82 , significantly below the scale midpoint $(p<0.001)$. The SD of 1.99 suggests variation in client identification between auditors. Finally, client size varies greatly in the sample.

\subsection{Hypothesis test results}

Table II presents Spearman's rank correlation coefficients for the variables (Spearman's rank correlations are preferable to Pearson's product-moment correlations because of the small sample size and because auditors' client acquiescence has a skewed distribution). The correlation between auditors' client acquiescence and transformational client leadership is not significant. However, this situation is not confirmed by the multivariate analysis, which is the actual hypothesis test, described in Table III, indicating that several factors that affect auditors' client acquiescence emerge only when we specify the situation by controlling for other relevant variables.

Continuing with the univariate analysis in Table II, the correlations reveal potentially significant relationships between several variables. A prerequisite for mediation is a relationship between transformational client leadership and identification. As expected, we observe a strong positive correlation between the variables $(p<0.01)$. Furthermore, we note a positive correlation between client identification and auditors' client acquiescence ( $p<0.01$ ), confirming previous findings (Bamber and Iyer, 2007; Stefaniak et al., 2012; Svanberg and Öhman, 2015).

The univariate analysis suggests no relationship between client identification and either auditor tenure or client size. The dichotomous variable Big 4 is correlated with several variables, indicating that Big 4 auditors identify more strongly with clients $(p<0.01)$ and perceive higher levels of transformational client leadership than do non-Big 4 auditors $(p<0.01)$. Moreover, Big 4 auditors seem to have larger clients $(p<0.05)$ but slightly shorter tenures $(p<0.05)$ than do non-Big 4 auditors.

\begin{tabular}{|c|c|c|c|c|c|c|}
\hline Variables & $\begin{array}{c}\text { Transformational } \\
\text { leadership }\end{array}$ & $\begin{array}{c}\text { Client } \\
\text { identification }\end{array}$ & $\begin{array}{l}\text { Auditor } \\
\text { experience }\end{array}$ & $\begin{array}{c}\text { Auditor } \\
\text { tenure }\end{array}$ & $\begin{array}{c}\text { Client } \\
\text { size }\end{array}$ & Big 4 \\
\hline $\begin{array}{l}\text { Auditors' client } \\
\text { acquiescence } \\
\text { Transformational }\end{array}$ & 0.134 & $0.260^{* * *}$ & 0.070 & -0.015 & $-0.207^{*}$ & 0.047 \\
\hline leadership & & $0.587 * *$ & 0.033 & 0.142 & 0.007 & $0.290 * *$ \\
\hline Client identification & & & 0.040 & 0.054 & -0.045 & $0.209 * *$ \\
\hline Auditor experience & & & & $0.467^{* *}$ & 0.055 & -0.094 \\
\hline Auditor tenure & & & & & -0.219 & $-0.151^{*}$ \\
\hline Client size & & & & & & $0.411 * *$ \\
\hline
\end{tabular}

Notes: Two-tailed tests. Variables: "Auditors' client acquiescence" measures the extent to which an auditor is lenient toward the client-preferred treatment. "Transformational leadership" is a one-component representation of transformational client leadership. "Client identification" is a variable capturing the extent to which an auditor identifies with a client. "Auditor experience" is the number of years the auditor has worked

Table II.

Spearman's rank correlations as an auditor. "Auditor tenure" is the length of time that the auditor has audited the largest client. "Client size" is the turnover of the auditor's largest client (SEK millions: USD 1=SEK 8.52, June 27, 2016). "Big 4" is 1 when the firm is one of the four largest auditing firms and 0 otherwise. ${ }^{*} p<0.05, * * p<0.01$ 


\begin{tabular}{|c|c|c|c|c|c|c|c|c|}
\hline \multirow[b]{2}{*}{ Dependent variable } & \multirow[b]{2}{*}{ Predicted sign } & \multicolumn{2}{|c|}{$\begin{array}{c}\text { Model } 1 \\
\text { Client } \\
\text { identification }\end{array}$} & \multicolumn{2}{|c|}{$\begin{array}{c}\text { Model } 2 \\
\text { Auditors' client } \\
\text { acquiescence }\end{array}$} & \multicolumn{2}{|c|}{$\begin{array}{c}\text { Model } 3 \\
\text { Auditors' client } \\
\text { acquiescence }\end{array}$} & \multirow{2}{*}{$\begin{array}{l}\text { Client } \\
\text { leadership } \\
\text { and auditor } \\
\text { objectivity }\end{array}$} \\
\hline & & Coefficient & Sig. & Coefficient & Sig. & Coefficient & Sig. & \\
\hline \multicolumn{9}{|l|}{ Variable } \\
\hline Client identification & + & & & & & 0.487 & 0.005 & \\
\hline Transformational leadership & $+/+/+$ & 0.593 & 0.000 & 0.662 & 0.000 & 0.390 & 0.024 & 1151 \\
\hline Auditor experience & $-/-/-$ & 0.000 & 0.961 & -0.003 & 0.439 & -0.002 & 0.453 & \\
\hline Auditor tenure & $+/+/+$ & 0.010 & 0.271 & 0.002 & 0.476 & -0.001 & 0.487 & \\
\hline Client size & $+/+/+$ & $2.433 \mathrm{E}-6$ & 0.665 & $-2.209 \mathrm{E}-5$ & 0.033 & $-2.144 \mathrm{E}-5$ & 0.033 & \\
\hline Big 4 & ?/?/? & 0.014 & 0.932 & -0.189 & 0.558 & -0.174 & 0.578 & \\
\hline$R^{2}$ & & 0.376 & & 0.184 & & 0.242 & & \\
\hline Adjusted $R^{2}$ & & 0.345 & & 0,138 & & 0.191 & & \\
\hline & & 12.059 & & 4.008 & & 4.689 & & \\
\hline \multicolumn{9}{|l|}{ Sig. $F$ for change between } \\
\hline Models 3 and 2 & & & & & & 0.011 & & \\
\hline \multicolumn{9}{|c|}{$\begin{array}{l}\text { Notes: As } H 1 \text { and } H 2 \text { are one-tailed, the significances of transformational leadership and client identification } \\
\text { in Models } 2 \text { and } 3 \text { are one-tailed. The tests of auditor experience in Models } 2 \text { and } 3 \text { and of auditor tenure in } \\
\text { Models } 1-3 \text { are one-tailed; all other tests are two-tailed. Variables: "Auditors' client acquiescence" measures } \\
\text { the extent to which an auditor is lenient toward the client-preferred treatment. "Client identification" is a }\end{array}$} \\
\hline
\end{tabular}

Because age and experience are highly correlated, we only present experience in Tables II and III and exclude age from the multiple regression models as a precaution to avoid multicollinearity. Moreover, we decided not to include gender in Tables II and III because previous research does not indicate that gender would affect the relationships of interest here and because the correlations and regressions did not reveal any indications of a relationship with the central variables of the study.

Table III presents data from the multiple regressions. Conditions for the suitability of linear regression were examined, including linearity, independent residuals, collinearity, skewness, kurtosis and normal distribution of residuals. Collinearity statistics were generated to verify that tolerance values were all below 1 . The values of the variance inflation factor were between 1.0 and 1.8, suggesting no multicollinearity. We investigated whether the residuals were normally distributed using the Shapiro-Wilk test and visual examination of the diagrams, all of which displayed approximately normal distributions.

We tested whether organizational identification mediates the impact of transformational leadership on follower behavior. If it can be assumed that client identification is caused by transformational client leadership, auditor tenure or client size, and if it can be assumed that auditors' client acquiescence is caused by transformational client leadership, client identification, auditor tenure or client size, then there is a possibility that client identification acts as a mediator between the precedent variables (i.e. transformational client leadership, auditor tenure and client size) and the dependent variable (i.e. auditors' client acquiescence). If this is the case, the effect of the precedent variables is mediated by client identification. The test of mediation is the statistical confirmation of causal modeling. We adopted a test of mediation described by Baron and Kenny (1986).

The mediating relationships between auditors' client acquiescence, client identification and transformational client leadership are explored using Models 2 and 3 in Table III. 
AAAJ

30,5

1152

In these models, the dependent variable is auditors' client acquiescence (in Model 1 the dependent variable is client identification).

Models 2 and 3 indicate support for $H 1$. The coefficient for transformational client leadership is significant in Model $2(p<0.001)$ and the size of the coefficient, 0.662 , suggests that transformational client leadership has a substantial impact on auditor objectivity. Controlling for client identification in Model 3 causes the magnitude of the coefficient to drop to 0.390 while the significance value increases to 0.024 , suggesting that a portion of the impact of transformational client leadership is indirect.

$H 2$ receives support from Models 1, 2, and 3 according to the mediation test. Model 1 provides evidence of a positive relationship between transformational client leadership and auditors' client identification $(p<0.001)$. A corresponding relationship between transformational leadership and organizational identification has recently been found (Effelsberg et al., 2014). Furthermore, the drop in significance levels for the transformational client leadership coefficient between Model $2(p<0.001)$ and Model $3(p=0.024)$ indicates that client identification mediates the impact of transformational client leadership on auditors' client acquiescence. Another criterion is the decrease in the size of the transformational client leadership regression coefficient between Models 2 and 3. Meeting both criteria for mediation, there is evidence that client identification partially mediates the impact of transformational client leadership on auditor objectivity. Thus, $H 2$ is supported.

Another significant relationship is the positive impact of client size on auditor objectivity. However, there is no significant difference between Big 4 and non-Big 4 auditors regarding their propensity to acquiesce to the client-preferred treatment. Moreover, auditor experience and auditor tenure appear to have no impact on the likelihood of acquiescing to client preferences during the audit.

\section{Discussion}

This paper examines the threat to auditor objectivity posed by transformational client leadership. Previous accounting research has, with few exceptions, focused on financial incentives, paying little attention to the bonding caused by social forces such as cognitivebased personal relationships with clients. The few studies of non-financial incentives have found that auditors' identification with their client firms poses a threat to auditor objectivity (Bamber and Iyer, 2007; Stefaniak et al., 2012; Bauer, 2015; Svanberg and Öhman, 2015) because auditors who identify with their client firms are more likely to acquiesce to client-preferred treatments during the audit process. The findings of these pioneering studies indicate that non-financial factors are serious threats to auditor objectivity that lie mostly under the surface remaining to be discovered. This study builds on the studies mentioned above, and the substantial amount of leadership research providing evidence that individuals who identify with a group or organization become more susceptible to influence from the group or organization leader (e.g. Howell and Shamir, 2005; van Knippenberg, 2011).

Our main finding, that transformational client leaders have the power to influence their auditors, supports the concerns raised regarding the threat to auditor objectivity from overly close relationships with client firms. The present finding is a significant contribution not only to accounting research, but also to the broader context of leadership research. The ability of transformational client leaders to influence audit judgment can be explained by findings in leadership research that such leaders are admired and respected and even inspire reverence in their followers (Conger et al., 2000; Walumbwa et al., 2004). It is argued that information provided by transformational leaders can be perceived as more trustworthy than information provided by other leaders, and transformational leaders can be perceived as benevolent, increasing followers' susceptibility to their influence (Giessner and van Knippenberg, 2008). 
Adapting leadership theories to the auditor-client relationship would be a productive avenue for future accounting research. While previous studies treat environmental factors that affect audit judgment, a type of analysis that at best provides a bird's-eye perspective on the auditor-client relationship (e.g. the impact of auditor tenure and the financial importance of the client firm), the leadership approach to this relationship permits analysis of the behavioral interplay between auditors and clients that occurs within their environment. Bamber and Iyer (2007) paved the way for the social identity approach, and the present study reveals the potential of the approach by introducing client leadership. It also contributes to the social incentives literature by identifying transformational client leadership as a potential antecedent of auditor-client identification. The finding that client identification partially mediates the impact of transformational client leadership on auditor objectivity is attested by leadership research demonstrating that follower organizational identification mediates the effectiveness of transformational leadership (Lowe et al., 1996; Judge et al., 2004; DeRue et al., 2011).

Moreover, this study contributes to the leadership literature by providing evidence of transformational leadership in an environment where the intergroup leadership challenge is likely to be difficult to surmount due to strong identity clashes. Client leadership capable of influencing auditors is an example of leadership across professional and organizational boundaries, referred to as intergroup leadership (Pittinsky and Simon, 2007). Leadership research has scarcely engaged itself with intergroup leadership: empirical evidence is lacking, and current leadership models have little to say about it (Hogg et al., 2012). The problem with intergroup leadership is that it must bridge intergroup clashes. For auditors, the identity clash can be described as one between a professional identity, stressing the public watchdog function, and a client identity in which the auditor's role is that of an advocate for the client firm (Jenkins and Lowe, 1999). Social identity theory would predict that auditors with strong professional identities tend to internalize professional norms and values and that auditors' behavior is strongly influenced by their identity. Considering the dependence of leadership effectiveness on follower identity, it is quite an accomplishment that client leaders can sometimes influence their auditors.

Our examination of auditors' identities is restricted to client identification. We do not know whether client leadership effectiveness depends on the establishment of an intergroup relational identity as predicted by Hogg et al. (2012), but we do find that transformational client leadership mediated by client identification can be a way to impair auditor objectivity. The finding that transformational client leadership has a negative effect on auditor objectivity does not preclude other forms of client leadership from having a similar effect.

Our study design included several control variables previously demonstrated to affect auditor objectivity. The control for financial dependence indicates that larger clients are associated with more objective audit judgment. One interpretation of this result is that larger clients are often audited by larger audit firms, but it is also possible that the higher litigation risk with large clients causes their auditors to be more cautious (cf. Reynolds and Francis, 2000; Carrington et al., 2013).

Limitations of this study include the modest response rate, potential non-response bias, and the measurement of auditors' client acquiescence using a constructed scenario. Specifically, our scenario design has the limitation that it cannot describe all the circumstances that would be relevant to the auditor's assessment. Because audit decisions are highly complex, it is impossible even for regulators to define in advance all situations and judgments auditors encounter and auditors often have to rely on professional judgment. Due to this complexity, any scenario is underspecified per definition. However, one limitation that applies specifically to the design of our scenario is that we did not ask auditors to specify to what extent unrecorded liabilities would be an important risk factor in relation to their largest client. The study would have benefited from knowing the client 
AAAJ

30,5

1154

firm's actual control environments and risk levels. Moreover, the study did not include all possible control variables. For example, Bamber and Iyer (2007) found that the effect of perceived client importance on auditor objectivity was fully mediated by client identification. These limitations suggest that the present results should be interpreted cautiously.

Nevertheless, as the present results indicate that transformational client leadership does affect auditor judgment, future research could continue to explore how various forms of client leadership affect auditor objectivity, and whether client leadership has an impact on other audit judgments and behaviors than those intimately associated with auditor objectivity. There is no lack of attempts at influencing auditors by persuasion. As noted by Gibbins et al. (2005), "CFO's and audit partners ordinarily concentrate on convincing the other party to accept their position." Furthermore, the finding that auditor-client identification may be caused by transformational client leadership is an important contribution to research into auditor social identity. Future research could examine this relationship in models that include additional antecedents of client identification.

The limitations of this study also suggest other issues that could be addressed by future research. Our cross-sectional research design does not admit causal inferences as to the relationship between clients' transformational leadership and auditor objectivity. Future studies could therefore examine whether the exercise of transformational leadership constrains auditor objectivity as a causal effect. Moreover, while this study focuses on the $\mathrm{CFO}$, it is possible that relationships with other client managers could also influence auditor judgment. Finally, adapting a conceptual framework from the leadership field and applying it to auditing may seem far-fetched, but given that autonomy can be viewed as the absence of influence, and that leadership can be considered as including influence, the theoretical link explored here suggests future research opportunities.

\section{References}

Avolio, B.J. (1999), Full Leadership Development: Building the Vital Forces in Organizations, Sage Publishers, Thousand Oaks, CA.

Bamber, E.M. and Iyer, V.M. (2007), "Auditors' identification with their clients and its effect on auditors' objectivity", Auditing: A Journal of Practice \& Theory, Vol. 26 No. 2, pp. 1-24.

Baron, R.M. and Kenny, D.A. (1986), "Moderator-mediator variable distinction in social psychological research: conceptual, strategic, and statistical considerations", Journal of Personality and Social Psychology, Vol. 51 No. 6, pp. 1173-1182.

Bass, B.M. (1985), Leadership and Performance Beyond Expectations, Free Press, New York, NY.

Bass, B.M. and Avolio, B.J. (1995), MLQ Multifactor Leadership Questionnaire: Sampler Set, Mind Garden, Redwood City, CA.

Bass, B.M., Avolio, B.J., Jung, D.I. and Berson, Y. (2003), "Predicting unit performance by assessing transformational and transactional leadership", Journal of Applied Psychology, Vol. 88 No. 2, pp. 207-218.

Bauer, T. (2015), "The effects of client identity strength and professional identity salience on auditor judgments", The Accounting Review, Vol. 90 No. 1, pp. 95-114.

Beattie, V., Fearnley, S. and Brandt, R. (2001), Behind Closed Doors: What Company Audit is Really About, Palgrave, Basingstoke.

Bono, J.E. and Judge, T.A. (2003), "Self-concordance at work: toward understanding the motivational effects of transformational leaders", Academy of Management Journal, Vol. 46 No. 5, pp. 554-571.

Boroş, S., Curşeu, P.L. and Miclea, M. (2011), "Integrative tests of a multidimensional model of organizational identification”, Social Psychology, Vol. 42 No. 2, pp. 111-123.

Carrington, T., Johansson, T., Johed, G. and Öhman, P. (2013), "An empirical test of the hierarchical construct of professionalism and managerialism in the accounting profession", Behavioral Research in Accounting, Vol. 25 No. 2, pp. 1-20. 
Conger, J.A., Kanungo, R.N. and Menon, S.T. (2000), "Charismatic leadership and follower effects", Journal of Organizational Behavior, Vol. 21 No. 7, pp. 747-767.

De Cremer, D. and van Knippenberg, D. (2002), "How do leaders promote cooperation? The effects of charisma and procedural fairness", Journal of Applied Psychology, Vol. 87 No. 5, pp. 858-866.

De Cremer, D. and Van Vugt, M. (1999), "Social identification effects in social dilemmas: a transformation of motives", European Journal of Social Psychology, Vol. 29 No. 7, pp. 871-893.

Den Hartog, M.H., Babuŝka, R., Deketh, H.J.R., Alvarez Grima, M., Verhoef, P.N.W. and Verbruggen, H.B. (1997), "Knowledge-based fuzzy model for performance prediction of a rock cutting trencher", International Journal of Approximate Reasoning, Vol. 16 No. 1, pp. 43-66.

DeRue, D.S., Nahrgang, J.D., Wellman, N. and Humphrey, S.E. (2011), "Trait and behavioural theories of leadership: an integration and meta-analytic test of their relative validity", Personnel Psychology, Vol. 64 No. 1, pp. 7-52.

Duck, J.M. and Fielding, K.S. (2003), "Leaders and their treatment of subgroups: implications for evaluations of the leader and the superordinate group", European Journal of Social Psychology, Vol. 33 No. 3, pp. 387-401.

Dvir, T., Eden, D., Avolio, B.J. and Shamir, B. (2002), "Impact of transformational leadership on follower development and performance: a field experiment", Academy of Management Journal, Vol. 45 No. 4, pp. 735-744.

Effelsberg, D., Solga, N. and Gurt, J. (2014), “Transformational leadership and follower's unethical behavior for the benefit of the company: a two-study investigation", Journal of Business Ethics, Vol. 120 No. 1, pp. 81-93.

Epitropaki, O. and Martin, R. (2005), "From ideal to real: a longitudinal study of the role of implicit leadership theories on leader-member exchanges and employee outcomes", Journal of Applied Psychology, Vol. 90 No. 4, pp. 659-676.

Gibbins, M., McCracken, S. and Salterio, S.E. (2005), "The congruency of audit partner and chief financial officer recalls", Auditing: A Journal of Practice \& Theory, Vol. 24, Supplement, pp. 171-194.

Gibbins, M., McCracken, S. and Salterio, S.E. (2010), "The auditor's strategy selection for negotiation with management: flexibility of initial accounting position and nature of the relationship", Accounting, Organizations and Society, Vol. 35 No. 6, pp. 579-595.

Giessner, S.R. and van Knippenberg, D. (2008), "License to fail': goal definition, leader group prototypicality, and perceptions of leadership effectiveness after leader failure”, Organizational Behavior and Human Decision Processes, Vol. 105 No. 1, pp. 14-35.

Hambrick, D.C., Li, J., Xin, K. and Tsui, A.S. (2001), "Compositional gaps and downward spirals in international joint venture groups", Strategic Management Journal, Vol. 22 No. 11, pp. 1033-1053.

Hellman, N. (2011), "Chief financial officer influence on audit planning", International Journal of Auditing, Vol. 15 No. 3, pp. 247-274.

Hobman, E.V., Jackson, C.J., Jimmieson, N.L. and Martin, R. (2011), "The effects of transformational leadership behaviours on follower outcomes: an identity-based analysis", European Journal of Work and Organizational Psychology, Vol. 20 No. 4, pp. 553-580.

Hogg, M.A. (2001), “A social identity theory of leadership”, Personality and Social Psychology Review, Vol. 5 No. 3, pp. 184-200.

Hogg, M.A. and van Knippenberg, D. (2003), "Social identity and leadership processes in groups", in Zanna, M.P. (Ed.), Advances in Experimental Social Psychology, Academic Press, San Diego, CA, pp. 1-52.

Hogg, M.A., van Knippenberg, D. and Rast, D.E. III (2012), "Intergroup leadership in organizations: leading across group and organizational boundaries", Academy of Management Review, Vol. 37 No. 2, pp. 232-255.

Hollingsworth, C. and Li, C. (2012), "Investors' perceptions of auditors' economic dependence on the client: post-SOX evidence", Journal of Accounting, Auditing \& Finance, Vol. 27 No. 1, pp. 100-122. 
AAAJ

30,5

1156

House, R.J., Spangler, D.W. and Woycke, J. (1991), "Personality and charisma in the US presidency: a psychological theory of leader effectiveness", Administrative Science Quarterly, Vol. 36 No. 2, pp. 364-396.

Howell, J.M. and Shamir, B. (2005), "The role of followers in the charismatic leadership process: relationships and their consequences", Academy of Management Review, Vol. 30 No. 1, pp. 96-112.

Jenkins, J.G. and Lowe, D.J. (1999), "Auditors as advocates for their clients: perceptions of the auditorclient relationship”, Journal of Applied Business Research, Vol. 15 No. 2, pp. 73-78.

Judge, T.A., Piccolo, R.F. and Ilies, R. (2004), "The forgotten ones? A re-examination of consideration, initiating structure, and leadership effectiveness", Journal of Applied Psychology, Vol. 89 No. 1, pp. 36-51.

Kadous, K., Kennedy, S.J. and Peecher, M.E. (2003), "The effect of quality assessment and directional goal commitment on auditors' acceptance of client-preferred accounting methods", The Accounting Review, Vol. 78 No. 3, pp. 759-778.

Kark, R., Shamir, B. and Chen, G. (2003), "The two faces of transformational leadership: empowerment and dependency", Journal of Applied Psychology, Vol. 88 No. 2, pp. 246-255.

Kark, R., Waismel-Manor, R. and Shamir, B. (2012), "Does valuing androgyny and femininity lead to a female advantage? The relationship between gender-role, transformational leadership and identification”, The Leadership Quarterly, Vol. 23 No. 3, pp. 620-640.

Larson, R. and Catton, W. Jr (1959), “Can the mail-back bias contribute to a study's validity?”, American Sociological Review, Vol. 24 No. 2, pp. 243-245.

LeBoeuf, R.A., Shafir, E. and Bayuk, J.B. (2010), "The conflicting choices of alternative selves", Organizational Behavior and Human Decision Processes, Vol. 111 No. 1, pp. 48-61.

Liao, H. and Chuang, A. (2007), "Transforming service employees and climate: a multilevel, multisource examination of transformational leadership in building long-term service relationships", Journal of Applied Psychology, Vol. 92 No. 4, pp. 1006-1019.

Lowe, K.B., Kroeck, K.G. and Sivasubramaniam, N. (1996), "Effectiveness correlates of transformational leadership and transactional leadership: a meta-analytic review of the MLQ literature", Leadership Quarterly, Vol. 7 No. 3, pp. 385-425.

McCracken, S., Salterio, S.E. and Gibbins, M. (2008), “Auditor-client management relationships and roles in negotiating financial reporting”, Accounting Organizations and Society, Vol. 33 Nos 4-5, pp. 362-383.

Mael, F.A. and Ashforth, B.E. (1992), "Alumni and their alma mater: a partial test of the reformulated model of organizational identification", Journal of Organizational Behavior, Vol. 13 No. 2, pp. 103-123.

Mayer, R.C., Davis, J.H. and Schoorman, F.D. (1995), "An integrative model of organizational trust", Academy of Management Review, Vol. 20 No. 3, pp. 709-734.

Mayhew, B.W., Schatzberg, J.W. and Sevcik, G.R. (2001), "The effect of accounting uncertainty and auditor reputation on auditor objectivity", Auditing: A Journal of Practice \& Theory, Vol. 20 No. 2, pp. 49-70.

Öhman, P. and Wallerstedt, E. (2012), "Audit regulation and the development of the auditing profession: the case of Sweden”, Accounting History, Vol. 17 No. 2, pp. 241-257.

Peus, C., Kerschreiter, R., Frey, D. and Traut-Mattausch, E. (2010), "What is the value? Economic effects of ethically-oriented leadership”, Journal of Psychology, Vol. 218 No. 4, pp. 198-212.

Piccolo, R.F. and Colquitt, J.A. (2006), "Transformational leadership and job behaviors: the mediating role of core job characteristics", Academy of Management Journal, Vol. 49 No. 2, pp. 327-340.

Pittinsky, T.L. and Simon, S. (2007), "Intergroup leadership", The Leadership Quarterly, Vol. 18 No. 6, pp. 586-605. 
Podsakoff, P.M., MacKenzie, S.B., Moorman, R.H. and Fetter, R. (1990), "Transformational leader behaviors and their effects on followers' trust in leader, satisfaction, and organizational citizenship behaviors", The Leadership Quarterly, Vol. 1 No. 2, pp. 107-142.

Reynolds, J.K. and Francis, J.R. (2000), "Does size matter? The influence of large clients on office-level auditor reporting decisions", Journal of Accounting and Economics, Vol. 30 No. 3, pp. 375-400.

Riketta, M. (2005), "Organizational identification: a meta-analysis”, Journal of Vocational Behavior, Vol. 66 No. 2, pp. 358-384.

Salterio, S.E. (1996), "The effects of precedents and client position on auditors' financial accounting policy judgment”, Accounting, Organizations and Society, Vol. 21 No. 5, pp. 467-486.

Schaubroeck, J., Lam, S.S.K. and Cha, S.E. (2007), "Embracing transformational leadership: team values and the impact of leader behavior on team performance", Journal of Applied Psychology, Vol. 92 No. 4, pp. 1020-1030.

Shamir, B. (1990), "Calculations, values, and identities: the sources of collectivistic work motivation", Human Relations, Vol. 43 No. 4, pp. 313-332.

Shamir, B., Breinin, E., Zakay, E. and Popper, M. (2000), "Leadership and social identification in military units: direct and indirect effects", Journal of Applied Social Psychology, Vol. 30 No. 3, pp. 612-640.

Shin, S.J. and Zhou, J. (2003), "Transformational leadership, conservation, and creativity: evidence from Korea”, Academy of Management Journal, Vol. 46 No. 6, pp. 703-714.

Stefaniak, C.M., Houston, R.W. and Cornell, R.M. (2012), "The effects of employer and client identification on internal and external auditors' evaluations of internal control deficiencies", Auditing: A Journal of Practice \& Theory, Vol. 31 No. 1, pp. 39-56.

Svanberg, J. and Öhman, P. (2015), "Auditors' identification with their clients: effects on audit quality", British Accounting Review, Vol. 47 No. 4, pp. 395-408.

Svanberg, J. and Öhman, P. (2016), "Does ethical culture in audit firms support auditor objectivity?", Accounting in Europe, Vol. 13 No. 1, pp. 65-79.

Sweeney, B. and Pierce, B. (2006), "Good hours, bad hours and auditors' defence mechanisms in audit firms”, Accounting, Auditing \& Accountability Journal, Vol. 19 No. 6, pp. 858-892.

Sweeney, B. and Pierce, B. (2011), "Audit team defence mechanisms: auditee influence", Accounting and Business Research, Vol. 41 No. 4, pp. 333-356.

Umar, A. and Anandarajan, A. (2004), "Dimensions of pressures faced by auditors and its impact on auditors' independence: a comparative study of the USA and Australia”, Managerial Auditing Journal, Vol. 19 No. 1, pp. 99-116.

Umphress, E.E., Bingham, J.B. and Mitchell, M.S. (2010), "Unethical behavior in the name of the company: the moderating effect of organizational identification and positive reciprocity beliefs on unethical pro-organizational behavior", Journal of Applied Psychology, Vol. 95 No. 4, pp. 769-780.

van Knippenberg, D. (2000), "Group norms, prototypicality, and persuasion”, in Terry, D.J. and Hogg, M.A. (Eds), Attitudes, Behavior, and Social Context: The Role of Norms and Group Membership, Erlbaum, Mahwah, NJ, pp. 157-170.

van Knippenberg, D. (2011), "Embodying who we are: leader group prototypicality and leadership effectiveness", The Leadership Quarterly, Vol. 22 No. 6, pp. 1078-1091.

van Knippenberg, D. and Hogg, M.A. (2003), "A social identity model of leadership effectiveness in organizations", in Kramer, R.M. and Staw, B.M. (Eds), Research in Organizational Behaviour, Elsevier, Amsterdam, pp. 245-297.

van Knippenberg, D. and Sitkin, S.B. (2013), "A critical assessment of charismatic-transformational leadership research: back to the drawing board?", The Academy of Management Annals, Vol. 7 No. 1, pp. 1-60.

van Knippenberg, D., van Knippenberg, B., De Cremer, D. and Hogg, M.A. (2004), "Leadership, self, and identity: a review and research agenda”, The Leadership Quarterly, Vol. 15 No. 6, pp. 825-856. 
AAAJ

30,5

1158

Walumbwa, F.O. and Hartnell, C.A. (2011), "The role of collective efficacy in the relations between transformational leadership and work outcomes", Journal of Occupational and Organizational Psychology, Vol. 84 No. 1, pp. 153-172.

Walumbwa, F.O., Avolio, B.J. and Zhu, W. (2008), "How transformational leadership weaves its influence on individual job performance", Personnel Psychology, Vol. 61 No. 4, pp. 793-825.

Walumbwa, F.O., Wang, P., Lawler, J.J. and Shi, K. (2004), "The role of collective efficacy in the relations between transformational leadership and work outcomes", Journal of Occupational and Organizational Psychology, Vol. 77 No. 4, pp. 515-530.

Wang, H., Law, K.S., Hackett, R.D., Wang, D. and Chen, Z.X. (2005), "Leader-member exchange as a mediator of the relationship between transformational leadership and followers' performance and organizational citizenship behavior", Academy of Management Journal, Vol. 48 No. 3, pp. $420-432$.

Wan-Huggins, V.N., Riordan, C.M. and Griffeth, R.W. (1998), "The development and longitudinal test of a model of organizational identification", Journal of Applied Social Psychology, Vol. 28 No. 8, pp. 724-749.

Yukl, G. (1998), Leadership in Organizations, Prentice Hall, New York, NY.

\section{Appendix. Measures used in the study}

\section{Transformational client leadership}

Apply the following statements to the leader of your largest client (i.e. the CFO). Please indicate your response between 1 (strongly disagree) and 10 (strongly agree).

The client leader instills pride in others for being associated with him/her.

The client leader goes beyond self-interest for the good of the firm.

The client leader speaks optimistically of the future.

The client leader speaks enthusiastically about what needs to be accomplished.

The client leader re-examines critical assumptions regarding their appropriateness.

The client leader looks for alternative perspectives when solving problems.

The client leader invests time in teaching and coaching.

The client leader treats others as individuals instead of simply members of the group.

\section{Client identification}

Scale: 1 (strongly disagree) and 10 (strongly agree).

When someone praises this client, it feels like a personal compliment.

When I talk about this client, I usually say "We" rather than "They."

This client's successes are my successes.

When someone criticizes this client, it feels like a personal insult.

I am very interested in what others think of my client.

\section{Auditors' client acquiescence}

Scale: 1 (very high likelihood) and 10 (very low likelihood).

Please respond to the following short audit case. We appreciate that normally you would require more information. However, for the purpose of our study we ask that you respond based on the limited information provided and assuming that the case involves your largest client referred to above.

In the current year's audit, a dispute has arisen between you and the management of your largest client over the materiality of certain unrecorded liabilities discovered by you during the audit. Professional and firm guidelines do not provide a definitive answer on the materiality of the amount involved. In your opinion, the amount is material. However, the client management strongly disagrees. The client's CFO argues that the total amount of unrecorded liabilities is immaterial and, therefore, it is unnecessary to make adjusting entries in the financial statements. As the auditor, how likely is it that you will not require these liabilities to be recorded? 


\section{About the authors}

Jan Svanberg is an Assistant Professor (PhD) of Business Administration in the Centre for Research on Economic Relations (CER) at the Mid Sweden University. His research interests are behavioral issues, primary in accounting and auditing.

Peter Öhman is a Professor (PhD) of Business Administration in the Centre for Research on Economic Relations (CER) at the Mid Sweden University. His research interests are primary in accounting, auditing and banking. Professor Peter Öhman is the corresponding author and can be contacted at: peter.ohman@miun.se

Presha E. Neidermeyer, $\mathrm{PhD}, \mathrm{CPA}$ (PhD Virginia Commonwealth University) is a Full Professor of Accounting in the Department of Accounting at West Virginia University. Her primary research interests are in international auditor behavior and gender issues.
Client

leadership and auditor objectivity

1159

For instructions on how to order reprints of this article, please visit our website: 